\title{
Az információ- és kommunikációs technológia (IKT) hatása az oktatási rendszerre, a távoktatásra és a partnerségi kapcsolatok fej
}

Collis, B. (1996): Tele-learning in a Digital World: The Future of Distance Learning. International Thomson Computer Press, London OECD (2001): E-learning: The Partnership Challenge, Education and Skill

A folyóiratban közölt müvek

a Creative Commons Nevezd meg! - Ne add el! - Így add tovább! 4.0 


\title{
Az információ- és kommunikációs technológia (IKT) hatása az oktatási rendszerre,
}

\author{
a távoktatásra és a partnerségi kapcsolatok \\ fejlődésére
}

Ivan Illich 1971-ben, hosszú idővel a világháló megjelenése előtt mondta: „Az a szándékom, hogy megmutassam a mai iskola ellentétének, a belsô motiváción alapuló tanulásnak a lehetôségét. Ahelyett, hogy tanárokat foglalkoztatnánk, hogy a diákokat rávegyék vagy rákényszerítsék a tanulásra, más módon is elérhetjük, hogy a diákok időt találjanak erre és akarjanak tanulni. Ahelyett, hogy a tanári munkára és az oktatási programokra koncentrálnánk, új kapcsolatokat tudunk biztosítani a tanulóknak a világhoz. A „hálózat” szót sajnos gyakran használják a mások által kiválasztott anyagok csatornáinak jelzésére... Bárcsak lenne egy másik szavunk erre... egy szinonima az »oktatási hálóra «".

Egy francia filozófus, Teilhard de Chardin már jóval korábban azt jósolta, hogy az oktatáson keresztül ki fog alakulni a „kommunikációs technológiák hálózata”, majd késốbb „az emberi tudatosság maga”. Mindkét kijelentés jóval megelőzte a korát.

Jelenleg már rendelkezésre állnak azok a technikák, amelyeket megjósoltak, jóllehet az osztálytermekben még nem használják ki ezeket.

Vajon az oktatási rendszer is változik? Fog-e alapvetôen változni az elkövetkezendô évtizedben? Hogyan lesz ez hatással a távoktatásra? Ezekre a kérdésekre keresi a választ Betty Collis 1995-ben íródott könyvében, melyben 2005ig állítja fel prognózisát.

\section{Az oktatási intézmények valóban meg fognak változni?}

Az oktatási intézmények múködésére az „inkább különféleképpen elvégezni ugyanazt, mintsem mást és mást hasonló módon” modell jellemző (Thornburg 1995). A távoktatást gyakran még mindig a levelezô oktatással (a távoktatás elsố fázisával) azonosítják.

\section{Szû̉k adminisztrációs keresztmetszet}

Moore 1993-ban felvetett egy adminisztrációs problémát: „....még mindig nincs olyan elismert ügynökség Észak-Amerikában, amelynek hatalmában állna, hogy független bizonyítványt nyújtson egyedileg összeállított oktatási programok elvégzésérôl, s amely az egyetemi és az üzleti környezetben hitelesnek számítana és 
összehasonlítható lenne a hagyományos egyetemek által kibocsátott diplomákkal”. Vannak együttmúködési projektek a különböző országok és területek között, de a strukturális változás az oktatási intézményekben lassú, túlzottan is lassú. Az intézményeknek a tanulást megkönnyítő helyekké kellene válniuk, és - mintegy „multimédia alapú könyvtárként”, információs és kommunikációs infrastruktúrát biztosítva a tanulók számára - többet kellene nyújtaniuk.

Fốként a felsôoktatásban várhatók - és történtek is már - változások, de ezek többnyire nem strukturális vagy a paradigmaváltás irányába mutató jellegúek, inkább a szemtől-szemben történő oktatás reprodukálását jelentik digitális környezetben. A virtuális tananyagok annál nagyobb mértékben hatnak, minél fiatalabbak a diákok. Erre jó példa, hogy 1995-ben - miután a diákok pornográf anyagokat tudtak elérni a Net segítségével - az Egyesült Államokban sokan úgy gondolták, szükség van az Internet szabályozására és ellenőrzésére. Itzkan úgy véli, hogy a jövốben a középiskolák a szerint lesznek osztályozva, hogy milyen mértékben férnek hozzá a hálózathoz, milyen szolgáltatásokkal vannak kapcsolatban, és hány diák használja ki ezeket a lehetôségeket.

Collis véleménye szerint az oktatás fejlődése során két, egymástól különbözô forgatókönyv alakul ki. Az első esetben a tanulók - valamely intézmény beiratkozott hallgatóiként - előre elkészített kurzusok anyagát dolgozzák fel, miközben a saját környezetükben, a saját munkahelyükön maradnak. A második forgatókönyv szerint a tanulók - saját speciális tanulási igényeik alapján - a távoktatás felé fordulnak. Ebben az esetben már inkább az egyéni igények alapján összeállított tananyag dominál. A tanulás történhet személyre szabott tananyagok vagy számítógép-alapú különórák segítségével. A távoktatás révén a tanulók képesek az effajta lehetőségeket munka mellett is kihasználni, és több lehetőségük van annak megválasztására, hogy mit és mennyit szeretnének tanulni.

A távoktatás jelenlegi és jövôbeni fejlődése négy fokozatban képzelhető el: az általános iskolában, a középiskolában, a felsőoktatásban és a gyakorlati életben. A felsőoktatásban a világháló használata mind mennyiségileg, mind minőségileg gyarapodni fog. Az általános iskolákban a távoktatás a kreativitás növelését célozza, mivel önálló feladatok megoldására ad lehetôséget. A középiskolákban a távoktatás segít kiterjeszteni a tanulási lehetőségeket.

A tanuláshoz felhasználható forrásanyagok egyre inkább elérhetôvé válnak elektronikus úton is, és így jóval nagyobb mélységben és terjedelemben válnak megismerhetővé, mint az iskolai oktatás keretében.

\section{Az új tanulási szokások leginkább a felsőoktatás területén figyelhetôk meg}

Az e-mail útján történő kommunikáció az oktatók és a diákok, illetve a tanulócsoportok tagjai között mindennapos rutinná válik. Az oktatók igénybevétele azonban nem csökkenni, hanem növekedni fog - annak következtében, hogy sokféle anyagot próbálnak nyújtani a diákok számára. Az anyagok mennyisége ugyanakkor csökkenni fog, hogy egyensúlyban legyen az oktatók által az egyes tanulókra on-line kapcsolatok során ráfordított idővel. A középiskolákban és az általános iskolákban az új tanulási szokások egyelőre még kevésbé érzékelhetôk, mint a felsőoktatásban. A kreatív tanároknak meglesz a lehetôségük és rendelkezésükre fognak állni az anyagok is ahhoz, hogy az osztályt a kapcsolatok létrehozása és a visszacsatolás érdekében 
„kiküldjék a világba”. Egyes vélemények szerint azonban csak nagyon kevés tanár fogja ezt a lehetôséget kihasználni, s ehhez nagyon hosszú idő szükséges.

\section{Oktatás az oktatási intézményeken kívül}

Az emberek nagy része tanul az iskolákon kívül. Jelentős részük nem azért tanul, hogy feljebb lépjenek a munkahelyi ranglétrán vagy hogy növekedjen a fizetésük, hanem csak okosabbá, múveltebbé szeretnének válni. Az oktatási intézményeken belül legtöbbször maga az oktató dönti el, mirôl mennyi anyagot szolgáltat a tanulni vágyóknak, az intézményeken kívül azonban a tanuló keresi meg a neki legmegfelelőbb képzési formákat.

Már 1995-ben megfigyelhető volt a tanárok szerepének jelentős visszaesése. A diákok és a szülốk a tanárok helyett a 24 órán át elérhetố hírprogramokhoz fordultak. Különböző problémáik megoldásához nem a tanárokat, hanem a világháló útján elérhetô forrásokat vették igénybe. Az Internet segítségével az emberek különféle anyagokat fedeztek fel, maguk is készítettek ilyeneket és ezeket kicserélték egymással. A diákok egyre inkább elvárják, hogy az iskolákon kívül - távoktatási formában speciális tanfolyamokon vehessenek részt.

A jövôben a szülő́k egyre inkább ilyen tanfolyamokra fogják beíratni iskoláskorú gyermekeiket, és az iskolák egymással versenyezni fognak a diákok megszerzéséért vagy éppen megtartásáért, mivel a diákok a távoktatási formában nyújtott kurzusokon az otthonukban tanulhatnak, távol az iskola épületétól, esetleg egy másik városban vagy egy másik földrészen.

Az oktatás egyre inkább a piaci verseny helyszínévé válik.

\section{Paradigmák az oktatásban}

\section{Személyes modellezés}

Ez a paradigma a gyermek közvetlen környezetében és a családon belül múködik, amikor például egy gyermeket a körülötte lévő személyek folyamatosan értékelnek, jutalmaznak és büntetnek. Az ilyenfajta tanulás személyes jellegú, de nem nevezhetố testreszabottnak. A fiatal lányok például megtanulnak ételeket elkészíteni, ruhákat varrni és a kisebb gyermekekre vigyázni - akár részt akarnak venni ebben a tanulási folyamatban, akár nem. A technológia itt az eszközök közvetlen felhasználását biztosítja.

2. Szakértốk bevonása

Egy bizonyos kor elérése után a gyermekeknek tudásuk fejlesztése érdekében már el kell hagyniuk megszokott, szúk környezetüket. Az első személy, akivel az addigi társaságukon kívül találkoznak, általában a vallás képviselóje, pap vagy lelkész, aki olyan speciális tudással rendelkezik, amivel a gyermekek szűk társaságukon belül addig nem ismerkedhettek meg. Ez a második paradigma minôségileg különbözik az elsôtốl. Távol a családi környezettôl a gyermekek új perspektívákat sajátítanak el, és új módszereket tanulnak meg azzal kapcsolatban, hogy bizonyos dolgokat hogyan tehetnek meg. A másokra való odafigyelés és a másik személy meghallgatása nyugodt körülmények között fontossá válik, majd idôvel növekszik a szakértő személy előadását hallgató csoport létszáma és nő annak a szerepe, hogy egy-egy képzett tanár 
hogyan tudja átadni tudását szavak segítségével. A kívánatos tanulási képességek elmozdulnak a figyelem és az emlékezés irányába. A személyes visszajelzés megfigyelhető, de már kisebb mértékben, mint az első paradigma esetében.

3. Távol lévő szakértôk bevonása - nyomtatott anyagok közvetítésével

A szakértố személyes jelenlétének fizikai határain túllépve - az írásos anyagok másolásának terjedésével és a viszonylag olcsó másolatok megjelenésével párhuzamosan - egyre több hétköznapi ember akarja megismerni, elolvasni magának a távol lévô szakértốk által előállított anyagokat. A tanulás azonban nem csupán a szavak elolvasását jelenti. Sok esetben nehéz megérteni a szavak jelentését. A tanár szerepe abban áll, hogy közvetítsen, segítsen az értelmezésben, vagy ő értelmezze a tanuló számára, hogy mire gondolt a szakember a szavak megfogalmazásakor.

A technológia szerepe a nyomtatással vált kritikus fontosságúvá: olcsó, könnyen reprodukálható, könnyen terjeszthető másolatok és az eredeti szövegek értelmezését segítő kiegészítô anyagok váltak elérhetôvé. A tanároknak ez további feladatokat jelentett. Nemcsak az eredeti szövegeket kellett elolvasniuk, hanem az azokról megjelent értelmezéseket is. Ekkor a tanárt és az eredeti szakértốt még számos szint (idô, távolság, értelmezés) választotta el. Előfordult, hogy az eredeti szerző́t nem lehetett többé megtalálni, s így az értelmezések bôséges lehetôségei maradtak nyitva.

\section{4. „Futószalag”}

A harmadik paradigma hatékony volt ugyan - olyan értelemben, hogy a nyomtatott szövegek sokkal több emberhez jutottak el, mint amennyit a szakértő hangja az órán elérhetett volna, az emberek mindhárom eddig jelzett paradigma esetében a saját sorsuk „börtönébe” zárva maradtak. Valamikor az ipari forradalom idején a technikai haladás segítségével vált lehetővé, hogy új, párhuzamos jelenségek vegyék kezdetüket az oktatásban. A futószalag segítségével sokkal többet tudtak termelni, mint korábban, és kevesebb költség merült fel. Mindez a jólét növekedésével járt együtt. A futószalaggal ugyanakkor nagy mennyiségú terméket dobtak a piacra, azzal a tudattal, hogy azok hasonlóak egymáshoz. Ehhez hasonló modell fejlődött ki az oktatásban is: kialakították az iskolák, a vizsgák és a tanfolyamok technikáját. Ez az a paradigma, ami a legtöbb technikai eszköz alkalmazásával jár, de a szakembereknek továbbra is fontos szerepük van abban, hogy meghatározzák és jóváhagyják azokat az anyagokat, amiket a tanulók elsajátítanak még az elốtt, hogy megjelennek a munkaerôpiacon. A hatékonyság és az állandó minőség elérése érdekében az oktatásban igen messzire lehet eljutni oly módon, hogy megmondjuk a diákoknak, mit olvassanak és hogyan gondolkodjanak. Az új típusú tudás világméretû gyarapodása során a helyi szakértôk egyre messzebb és messzebb kerülnek attól, hogy a diákok számára közvetítốk maradhassanak.

\section{5. Összekapcsoltság}

A virtuális kommunikáció segítségével képesek leszünk a szakértôkkel kommunikálni, függetlenül a helytôl és a körülményektôl. Új lehetôség nyílik tehát arra, hogy egymástól tanuljunk. Nemcsak a kapcsolat iránt nő meg az igényünk, hanem megváltoznak a lehetőségeink is a tananyagok elérésére. A kapcsolatok segítségével egy-egy témával kapcsolatban nemcsak egy perspektíva jelenik meg, hanem több különbözó alternatíva. Ennél is sokkal nagyobb jelentőségú azonban, hogy a hálózati kapcsolatok segítségével magát a szerzốt is elérhetjük. A második paradigmához hasonlóan közvetlen kapcsolatba léphetünk a szakértôvel, azonban itt a kapcsolatnak nem a szakértő hangja által betölthetố tér szab határt, hanem az, hogy a szakértő hajlandó-e 
válaszolni az e-mail útján hozzá eljuttatott üzenetekre. Az új lehetôségek sorának megvan az ára is. A tankönyveknek mint a tudás forrásainak a használata le fog értékelődni, a szerző́k pedig nagy nyomás alá kerülhetnek.

\section{Más utak a fejlődéshez}

Azt, hogy a távoktatás saját formái, módszerei és szervezetei hogyan fognak kialakulni, egyelőre még nem lehet tudni. Még az sem világos, hogyan fog megváltozni, átalakulni a tanárok szerepe. A legtöbb, amit kérhetünk valakitôl az, hogy segítsen a döntések meghozásában. A jelenlegi és a jövőbeli tanárok közti különbség pedig abban áll, hogy a jövőbelieket mi fogjuk magunknak kiválasztani. Ennek is megvan azonban a maga kockázata. Még nem tudjuk, hogy milyen szempontok alapján fogjuk a tanárokat és a tananyagokat kiválasztani magunknak. Hogyan fogja a társadalom tolerálni a választás szabadságát az oktatás területén? Néhány fontos változás valószínúleg be fog következni: a távoktatás például el fogja homályosítani a különbséget a szakértők és a nem-szakértők között, megtöri a tankönyvek dominanciáját és versenyt jelent a tanárok és a tananyag kiválasztása terén.

Az OECD Oktatáskutatási és Innovációs Központja által 2001-ben kiadott „Etanulás (Partnerségi erôpróba)" címú jelentés az IKT eszközök elterjedésének hatásait vizsgálja az oktatásban. Ebben a tanulmányban - az új kihívásokra adott válaszként kiemelt hangsúlyt kapnak a különféle szintû́ társulási (partneri) kapcsolatok.

Az Internet mint jelenség példa nélkül áll a technológiai újítások történetében, akár a hozzáférési lehetôségek növekedését, akár a térhódítás ütemét nézzük. Az új technológiák lehetôvé teszik az információk gyorsabb átalakítását ismeretekké, illetve az új információk és ismeretek létrehozását és gyors terjesztését. Az Egyesült Államok egyértelmúen élen jár ezen a téren, míg a többi ország között jelentôs eltérések mutatkoznak.

Az információs és kommunikációs technológiák alapvető hatással vannak nemcsak a gazdasági fejlôdésre, hanem a kultúrára, a társadalmi életre és az oktatás rendszerére is. Az Internet-használók számára vonatkozóan közzétett adatok ritkán tudnak lépést tartani a növekedés ütemével és a legjobb esetben is csak erôsen hozzávetôlegesek.

A hálózati technológia elterjedése eddig a munkahelyeken volt a legnagyobb arányú, de ebből a szempontból az otthonok, az iskolák és a közösségi központok, köztük a könyvtárak helyzete is egyre jobb. Az OECD országok figyelmébe ajánlott egyik kérdés a munkahelyek, a felsőoktatás és a gyakorlati szakképzés iránt megnyilvánuló fokozott érdeklődés, ami az oktatási piacot jellemzi. Széles körû egyetértés mutatkozik abban, hogy az oktatási célkitűzések elérése érdekében az úgynevezett tanulóévek során különösen a szakmai oktatás és képzés elsô éveiben lehet a legnagyobb előrelépéseket tenni. 


\section{Az IKT következő generációja}

Az IKT folyamatosan fejlődik. A fejlődés azzal az ígérettel biztat, hogy a hálózati alkalmazások újabb generációja minôségi ugrást hozhat a mai Internet technológiai lehetôségeihez képest. A már széles körben tapasztalható trendek bizonyítják az Interneten elérhetô új, gazdag erőforrások oktatási alkalmazásának a lehetôségét. A web-alapú oktatással foglalkozó bizottság 2000. decemberi jelentése (Kerrey 2000) a fontosabb trendek közül az alábbiakat emeli ki:

Először is, az elkövetkezendő néhány évben a szélessávú Internet-csatlakozás lehetôségei várhatóan exponenciálisan növekedni fognak. A második trend a máris mindent átható számítástechnika további térhódítása, ami a vezeték nélküli kommunikációs technológiákkal megvalósítható átvitel útján lehetővé teszi számos kisebb, többcélú készülék összekapcsolását egymással, a hálózatokon keresztül.

Celluláris átjátszó állomásokat építeni sokkal olcsóbb, mint kilométernyi kábelt lefektetni. A vezeték nélküli megoldások révén - vezeték nélküli telefonokon, kétirányú személyhívókon és egyéb kézi készülékeken keresztül - a távoli és az elmaradott területek is hamarosan élvezhetik a világháló előnyeit.

A harmadik trend a digitális konvergencia, ami egyesíti a rádió, a televízió, a telefon és más interaktív kommunikációs eszközök lehetőségeit. A televízió mindenütt jelenlévő infrastruktúráját jelentős mértékben javítja a digitális átvitelre való áttérés, amire egyre több OECD országban sor került. A megnövelt átviteli kapacitás révén az állomások hatalmas mértékben kibővített programokat képesek sugározni. A hagyományos mủsorszórás mellett lehetôvé válik gazdag kiegészítő információcsomagok „adat-sugárzása” (datacasting). Ezek a csomagok tananyagokat, szoftvereket és kezelési útmutatókat tartalmazhatnak, szöveges, video vagy audio formátumban továbbítva. A közvetlen múholdas kapcsolatok segítségével gazdagabb információtartalmú anyagokat lehet közvetíteni.

A negyedik trend a sávszélesség egységre vonatkoztatott költségeinek drasztikus csökkenése. A sávszélességgel arányos költségek csökkenni, az átviteli teljesítmény pedig - a Moore törvény által jelzettnél gyorsabb ütemben - növekedni fog. A mindenütt jelenlévô Internethez való hozzáférés reális lehetôséggé válhat nemcsak a korábbi kiváltságosok, hanem mindenki számára.

A web-alapú oktatással foglalkozó bizottság által megfigyelt többi trend kifejezetten az oktatási ágazatot érinti. Ezek között szerepel a tartalom-fejlesztésre és megosztásra vonatkozó múszaki szabványok és megállapodások érvényesülése, amitôl a web-alapú tanulási környezetek fejlődésének előmozdítása várható, valamint olyan adaptív technológiák kialakulása, amelyek a beszédfelismerést, a mozdulat-felismerést, a szövegek beszéddé való átalakítását, a nyelvek közötti fordítást és az érzékszervi tapasztalást egyesítve lényegi változásokat generálnak a hálózat révén kibővülő emberi érintkezésben.

\section{Az Internet hatása a gazdaság különböző ágazataira}

„Az Internet - talán a történelem leginkább mindent átformáló hatású technológiája - megdöbbentő módon alakítja át az üzleti életet, a médiát, a szórakozást és magát a társadalmat. Minden ereje ellenére azonban csak most kezdjük felhasználni az oktatás átalakítására" (Kerrey 2000). 
A szélessávú hozzáféréstől azt várjuk, hogy jelentôs hatással legyen a tudásalapú társadalom fejlődésére az által, hogy az Internet az oktatás, a gazdasági élet és a kommunikáció fố eszközévé válik. A szélessávú és vezeték nélküli Internet-technológia alapvetően meg fogja változtatni a szórakoztató, információs és oktatási szolgáltatásokat.

A szélessávú és vezeték nélküli Internet sikerének biztosítása érdekében az egyik legsürgetôbb igény a tartalom és a kommunikáció új, innovatív formáinak kialakítására irányul.

\section{IKT beruházások az oktatásban}

Az oktatási ágazatban a kormányzatok által végrehajtott IK'T beruházások két fő csoportját az alábbiak alkotják:

- bizonyítottan stabil technológiák, fóként a hardver és az infrastruktúra terén;

- kísérleti és fejlesztési tevékenységek beruházásai - fôként olyan fejlett technológiák alkalmazása terén, amelyek a legmodernebbek közé tartoznak ugyan, de hozzájárulási lehetôségeik a tanulás fejlődéséhez még nem bizonyítottak.

Az OECD országok az elmúlt négy év során komoly IKT beruházásokat hajtottak végre az oktatásban. „1999-ben az OECD egészére vetítve hozzávetőlegesen 16 milliárd amerikai dollár értékủ beruházás történt - ez a teljes oktatási kiadásoknak még mindig csak 1-2\%-a, de azért óriási erôforrás" (OECD 1999). A beruházások legnagyobb részére a hardver és az infrastruktúra területén került sor.

Miközben a hardver, a szoftver és a távközlési szolgáltatások terén végrehajtott beruházások minden OECD országban gyorsan növekednek, a háztartásokban és az oktatási intézményekben az erôforrások továbbra is egyenlôtlenül oszlanak meg.

Az iskolák és az oktatási szervek tisztában vannak azzal, hogy az IKT beépítése a tanításba és a tanulásba rendkívül fontos - egyrészt ahhoz, hogy a tanulók felkészülhessenek az információs társadalomra, másrészt pedig ahhoz, hogy az új tanulási eszközöket a lehető legjobban ki tudják használni. Az iskolákat, könyvtárakat és tanulási központokat arra biztatják, hogy vásároljanak új számítógépeket és bővítsék lehetôségeiket az Internet-hozzáférés terén, ez által enyhítve azoknak a tanulóknak a hátrányos helyzetét, akik otthon nem rendelkeznek Internet-hozzáférési lehetőséggel, de így a tanulási és információs erőforrások valamelyik közintézményben számukra is elérhetővé válnak.

A web-alapú oktatással foglalkozó bizottság ún. Kerrey-jelentése (Kerrey 2000) kiemeli az iskolák Internet-csatlakozással való ellátottságának gyors javulását. A jelentés azonban arra is rávilágít, hogy a gazdagabb és a szegényebb iskolák között lényeges eltérések mutatkoznak.

A Knowledge Web adatai szerint 1998-ban az Egyesült Államok felsőoktatási intézményei hozzávetőlegesen 3,1 milliárd dollárt költöttek informatikára, s ebből az összegbốl körülbelül 9,8\%-ot, azaz 305 millió dollárt a távoktatás támogatására fordítottak.

A magán szektor érdeklôdése is egyre nô az oktatási ágazat iránt. Az oktatás igen vonzó ágazat, magas növekedési reményekkel az elkövetkező évekre nézve. 


\section{Melyek az oktatási technológia lehetséges hatásai?}

Az IKT oktatási lehetőségeinek tisztázása érdekében a kulcskérdés az, hogy a technológia és a digitális média segítségével a tanítási és tanulási folyamatok mely részeit lehet a leginkább hatékonnyá tenni. A technológia segítségével az információkat, ismereteket és tapasztalatokat új módon lehet bemutatni, s ezáltal új tanulási célok határozhatók meg és új eredmények érhetôk el. A IKT a teljes oktatási folyamatra - a tanulási környezetre, a tanulás tartalmára, a tanulók képességeinek fejlesztésére és a kommunikáció alkalmazott formáira is - átfogó hatást gyakorol.

\section{Az IKT hatása a következốképpen érvényesül:}

\section{A tanulási környezetek}

A tanulási környezet megválasztásának lehetőségeit hagyományosan a tantermek, a könyvtár, a laboratórium, a munkahely és az otthon helyszíneit figyelembe véve képzeltük el. Az IKT megjelenésével azonban ezek a határvonalak elmosódnak. A tanulás a legkülönbözôbb helyszínek egész sorában folyhat mind fizikailag, mind virtuálisan. A tanulók most már valóban választhatnak és egyre inkább szeretnék ötvözni a választási lehetôségeket, amikor eldöntik, hogy mikor és hol akarnak tanulni. Az oktatást nyújtó szakemberek számára kihívást jelent az anyagok és szolgáltatások elốkészítése és integrálása, ugyanis az IKT alapvetôen megváltoztatja és kiterjeszti a tanulási környezetet.

\section{A tanulási tartalmak}

Érdemes megkülönböztetni a „rögzített” és a „folyékony” tartalmakat. Rögzített tartalomról akkor beszélünk, amikor az oktatók, tantervkészítôk és tananyag-szerzók határozzák meg, hogy mi az, amit a tanterv részeként meg kell tanítani. Ugyanakkor az IKT terjedésével a tanulók számára egyre könnyebben és egyre függetlenebbül megvalósítható hozzáférést lehet biztosítani - például az Interneten keresztül - a lényeges információk óriási tömegéhez, többféle kommunikációs tevékenység útján. Ez utóbbi, kevésbé szabályozott ismeretforrásokat nevezhetjük folyékony tartalmaknak.

\section{A tanulók képességeinek fejlesztése}

A IKT fejlesztheti a tanulók képességeit az által, hogy vonzó és hatékony választási lehetőségeket biztosít a tanuláshoz. Az IKT a különböző tanulási stílusok és preferenciák egész sorának képes megfelelni. Az általa kínált tanulás kulcsfontosságú jellemzôje a különféle média-típusok erôforrásainak, stílusainak és módszereinek ötvöződése az interaktív multimédia szolgáltatásokban.

\section{A kommunikáció}

A IKT révén megvalósuló érintkezés történhet úgy, hogy egy ember egy másikkal, egy-többel vagy több-többel kommunikál. A IKT projektekben érintett 
oktatási szolgáltatók világszerte dolgoznak azon, hogy feltárják ezeknek a módozatoknak az erôsségeit és gyengeségeit.

\section{Előnyök bistositása az IKT segitségével}

Amit csak a technológia segítségével lehet elérni:

- az idő és a tér korlátainak „megszúnése” - tanulás bárhol és bármikor;

- tömeges oktatás - mindenki számára elérhetô tanulás;

- hozzáférés egyre bôvülő oktatási erôforrásokhoz és szolgáltatásokhoz az Internet útján;

- gyorskereső és megjelenítő szoftverek alkalmazása feladatok megoldására épülô tanuláshoz, illetve kutatási munkához;

- igény szerinti tanulás;

- társak tanítása és tanulása távoktatáson keresztül.

\section{Amit a technológia segítségével jobban lehet megoldani:}

- a tanulási stílus megválasztása;

- egyedi, egyénre szabott tananyagok és szolgáltatások;

- a tanulási folyamatok egyénenkénti követése és rögzítése;

- a tanuló teljesítményének értékelése és figyelése;

- interaktív kommunikáció a tanulási folyamat résztvevói és befolyásolói között;

- interaktív hozzáférés az oktatási erőforrásokhoz.

A IKT oktatási potenciálja röviden így jellemezhetô: több ember részesedése jobb oktatásban, alacsonyabb költségek mellett.

Az OECD tagországokban mintegy hat éven keresztül folyt jelentős IKT beruházások keretében számos fejlesztési projekt és program valósult meg. Ezek között voltak olyanok, amelyek sikeresek voltak és voltak olyanok is, amelyek nem. Sok tapasztalat gyúlt össze többféle szinten, ezekből értékes tanulságokat lehetett levonni. Mindazonáltal - annak ellenére, hogy az OECD tagországokban 1999-ben 16 milliárd amerikai dollárt költöttek az információ- és kommunikációs technológiára nem sok adat utal arra, hogy az IK'T teljesíti eredeti ígéretét, miszerint több ember jobb oktatásban, alacsonyabb költséggel fog részesülni.

Az információ- és kommunikációs technológiákat az oktatási gyakorlatban alkalmazó szakemberek közül sokan meg vannak győződve azok előnyeiről és nem is tudnák elképzelni, hogy visszatérjenek egy IK'T nélküli tanulási környezethez. Ugyanakkor nincs egyértelmú bizonyíték arra vonatkozóan, hogy az állami szektor IK'T beruházásai javítottak volna a tanárok, illetve a tanulók teljesítményén, vagy akár az oktatási erőforrások minőségén. Az érintettek tömegeinek kell végighaladniuk a tanulási pályán, mieloótt az új oktatási piac valóban megnyílhatna. 


\section{Az információhordozótól a tartalomig}

A technológia önmagában nem garantálja az oktatási sikert. Csak akkor jelent értéket az oktatásban, ha segítségével a tanulók és a tanárok valami hasznosat tehetnek. Mára számos OECD országban már egyértelműen látható a hangsúly eltolódása a technológia irányából a tartalom és az emberek felé.

Az új infrastruktúra, a személyi számítógépek és az Internet-csatlakozás elterjedése szükséges ahhoz, hogy a szoftverek és az oktatási alkalmazások múködhessenek. Másfelól viszont, ha kevés az elérhetô oktatási szoftver és tartalom, ez csalódást okoz és sok tanárt és tanulót mindörökre eltávolít az on-line tanulási tapasztalatoktól. A helyzet javulásához a figyelmet lekötô, hatékony on-line tartalomra van szükség. Az IKT támogatásával történố tanulásra felkészítô hatékony tanárképzés sem valósulhat meg a megfelelő tartalmak és alkalmazási formák kidolgozása és együttesen elérhetővé tétele nélkül.

$\mathrm{Az}$ Internet és a számítástechnika múködését biztosító infrastruktúra a múködéséhez szükséges szoftverekkel és egyéb eszközökkel együtt - a helyi eltérésektől, a nyelvektől és a kultúráktól többé-kevésbé függetlenül - világméretekben előállítható. Az oktatási tartalmak és az e-tanulási szolgáltatások terén azonban nem ez a helyzet. Ezeket a helyi kultúrához és a konkrét igényekhez kell igazítani. Az e-tanulási szolgáltatások kínálatának javításában egyre nagyobb problémát jelent a globális infrastruktúra és a lokális tartalom közötti feszültség. Az IK'T infrastruktúra globális beszállítóitól nem várhatók el a helyi tanulási környezetekhez adaptált hatékony oktatási szoftverek és szolgáltatások. Számos társulás, ami az IKT területén múködő vállalatok és az oktatási tartalomszolgáltatók között jött létre, éppen ezen bukott meg.

Ami az egyik kultúrában megfelelô, az nem feltétlenül alkalmazható egy másikban. A kereskedelmi forgalomban kapható oktatási szoftverek nagy részét amerikai szoftvergyártók készítik. Ezek a világpiacon általában nem bizonyulnak sikeresnek. A korai piaci bukás egyik oka a hálózaton elérhető hatékony tananyagok és más források hiánya. Bár a helyzet fokozatosan javul, a jó tartalomszolgáltatók hiánya továbbra is jelentős korlátozó tényezőt jelent. Ahhoz, hogy versenyképesek maradjanak és elérjék az IKT területén végrehajtott beruházások valódi megtérülését, az egyes országoknak több energiát kell fordítaniuk a tartalom elôállítására.

Az online oktatási szolgáltatások fejlesztésében nagy hiba az analóg környezet utánzása, és a tantermi oktatáshoz készült vagy az egyetemi előadásokból összeállított tanfolyamok puszta digitalizálása és másolása. Az online oktatásnak az oktatás újra-feltalálását, az Internet, a digitális televízió és az elektronikus megjelenítésre szolgáló új eszközök hatékony felhasználását kell jelentenie. A könyv tökéletes médium, de csak a legritkább esetben múködik a képernyőn is. Ugyanakkor a képernyő és az interaktív számítástechnika segítségével sokkal többet is megtehetünk, mint ami csupán könyvek felhasználásával lehetséges. Az analóg és a digitális média jellemzőinek ötvözésével az online oktatás végül rendkívüli sikerre vihető.

\section{A partneri társulások}

A társulás bármilyen típusának sikere szempontjából alapvetô fontosságúak a világos célkitûzések. Az oktatási intézmények XXI. század eleji szótárában központi helyet foglal el a „társulás” kifejezés. Az együttmúködő szervezetek integrációja - az 
interakció és az egymásrautaltság mértékétől függően - a legkülönbözőbb formákat öltheti fel. A jelenlegi irányadó nézet szerint a társulások jelentik a jövő útját, és az e-tanulási lehetôségek kihasználására törekvố intézmények jól teszik, ha stratégiai döntést hoznak különféle szövetségek megkötésérôl. Az egyetemek autonóm intézmények, de a tudásalapú gazdaságban a vállalkozó szellem az egyetemeken éppen olyan fontossá válik, mint a gazdasági vállalkozásoknál. Azok az egyetemek, amelyek „nem tesznek semmit”, nem fognak fennmaradni - és nem a kormányok feladata lesz kihúzni ôket a bajból (Blunkett 2000).

Az e-tanulási társulások különbözổ ismérvei

\begin{tabular}{ll}
$\begin{array}{l}\text { Hatáskör } \rightarrow \\
\text { Partnerek száma } \rightarrow\end{array}$ & $\begin{array}{l}\text { A helyi, regionális és országos hatáskörtôll } \\
\text { egészen a nemzetek közötti hatáskörig }\end{array}$ \\
\hline Ágazat $\rightarrow$ & Egy vagy néhány partnertôll sok partnerig \\
\hline Kötelezettség-vállalás $\rightarrow$ & Tagság ugyanabból az ágazatból és más ágazatokból is \\
\hline Önkéntesség $\rightarrow$ & Határozott idejû vagy hosszú távú kötelezettség-vállalás \\
\hline Irányítás $\rightarrow$ & $\begin{array}{l}\text { Az önkéntes szövetségektốl a kierốszakolt egyesülésig } \\
\text { vagy felvásárlásig és a partnerekre ráerôltetett társulásig }\end{array}$ \\
\hline Kormányzás $\rightarrow$ & $\begin{array}{l}\text { A szerves irányítástól a megosztott } \\
\text { hatáskörökön át a formális hierarchiáig }\end{array}$ \\
\hline Méret $\rightarrow$ & $\begin{array}{l}\text { A laza szövetségtól a jól körülhatárolt és } \\
\text { szabályozott szövetségig }\end{array}$ \\
\hline Az együttmúködés mértéke $\rightarrow$ & $\begin{array}{l}\text { Az együttmúködés szúkebb, meghatározott } \\
\text { területétôl az intézmények egészére vagy } \\
\text { több szervezetre kiterjedő együttmúködésig }\end{array}$ \\
\hline
\end{tabular}

Angliában például az ipar tanulási erôforrásainak és lehetôségeinek laza hálózati együttmúködéseként indult szövetség az ország egész területén tanulási központokkal rendelkező, országos méretű korlátolt felelősségű társasággá vált.

Egy másik trend az egyetlen vagy néhány tagból álló társulások egyszerủ formáitól való elmozdulás a több szervezetet is tömörítő társulási formák felé. Az oktatási intézmények az előtt a stratégiai válaszút előtt állnak, hogy vagy mindent egy lapra tegyenek fel, vagy megosszák a kockázatot, s ezért inkább nemcsak egy vállalattal társulnak, egy bizonyos kezdeményezést egyetlen fajta technológiával követve, hanem különbözô partnerek között osztják fel a társulási formában végzett tevékenységeiket.

Sok esetben tapasztalható elmozdulás az ugyanahhoz az ágazathoz tartozó szervezetek közötti társulások és egyesülések irányából az összetettebb, több ágazatot átfogó társulások és szövetségek felé, amik az oktatási intézmények, a média és a nagyvállalatok között gyakran nemzetközi szinten jönnek létre. Ezt a trendet csak gyorsítja az ágazatok közötti határvonalak elmosódása, ami leginkább az információs szórakoztatóipar („,infotainment”) területén nyilvánul meg. Dussauge, Garrette és Mitchell ezeket a társulásokat „kapcsolat-szövetségeknek” nevezik. A szövetségek leggyorsabban növekvő fajtája „az olyan, erősen változékony kapcsolat-szövetség, amelyben a partnerek mindegyike eltérő erôforrásfajtával járul hozzá a társuláshoz”. 
Az e-tanulási társulások típusai

Byrkjeflot (Byrkjeflot 2000) a felsőoktatás és az általánosabb jellegű vállalati tanulás fejlődésének kontextusában az üzleti oktatásról szólva az e-tanulási szövetségek egyszerû osztályozását javasolta, a társulásokat az érintett társak profilja és azonos vagy eltérő ágazathoz való tartozása szerint két ismérv mentén helyezve el.

Byrkjeflot négy társulási típusa a következő:

Média-média szövetségek, például oktatási profilú kiadóvállalatok szövetkezései;

oktatás-oktatás szövetségek, például felsőoktatási intézmények társulásai egymással bizonyos kurzusok lebonyolítására;

oktatás-média szövetségek az oktatási intézmények és egyes szolgáltató vállalatok között;

egyéb szövetségek (esetleg több különböző profilú intézmény bevonásával).

\section{A társulások hajtóereje}

A felsôoktatást említve Byrkjeflot (Byrkjeflot 2000) arra utal, hogy a média, az oktatási intézmények és a vállalatok négy okból kifolyólag alakítanak ki egymással szövetségre lépve szorosabb kapcsolatokat, illetve társulásokat. Ezek a következôk: konvergencia, strukturális „lyukak”, márkanév-biztosítás, globalizáció.

A tanulási piacok konvergenciája az új tanulási és média-technológiák fejlődésének következménye. Míg néhány ével ezelőtt a szórakoztatóipar és a tanulási ügyfélszolgálat, valamint a munkavállalói és felnőttoktatási piac még elég jól elkülönültek egymástól, most gyors konvergenciájuk tapasztalható. Míg korábban a hagyományos oktatás területe számított a legfontosabbnak, a munkavállalói tanulás és az „oktatási szórakoztatóipar” („edutainment”) igényei az elmúlt évtized során sokkal nagyobb mértékben növekedtek. Az e-tanulás iránt a legnagyobb potenciális kereslet a fogyasztási és szórakoztatóipari ágazatban várható, míg a munkavállalói tanulás a második helyre számíthat, a diákok pedig a harmadik legnagyobb piacot fogják jelenteni. A strukturális „lyukak” akkor keletkeznek, ha a szereplők lehetőséget látnak a társadalom olyan tagjai között fennálló szakadékok áthidalására, akik a technológiai eszközök híján nem kerülnének kapcsolatba egymással. Kérdés, hogy az ilyen szakadékok áthidalása terén milyen közvetítők, illetve vállalkozók vannak a legkedvezôbb helyzetben. Az e-tanulási szövetségek fejlődése mögött meghúzódó harmadik ok a márkanév-biztositás. A márkanevek státusz-hierarchiájában előkelő helyért folyó küzdelemben, melynek során az oktatásban is versenyelőnyhöz jutnak azok, akik a legismertebb, legjobban bevezetett nevet mondhatják a magukénak, az információs technológiák alapvetố szerepet játszanak. Az „egyetem” elnevezés használata még mindig a kiváló minőséget, az ott dolgozó szakemberek, a szolgáltatások, a termékek és a tanulási folyamatok egységesen magas színvonalát sugallja. Mivel a márkanevek konkrét minőségekhez és ágazatokhoz kapcsolódnak, várható, hogy az oktatási tartalomhoz tartozó márkanevek kialakításában az e-tanulás korában is a legmagasabb rangú és legismertebb egyetemek jutnak kulcsszerephez. A média-vállalkozások a jól ismert márkanevek más ágazatokban való kihasználásában, illetve a felsôoktatási fogyasztóknak - saját márkanevük segítségével - új e-tanulási piacokra való csábításában csak egy bizonyos pontig mehetnek el. A márkanevek hordozói egyelőre 
még az egyetemek. A felsőoktatás terén erôs a nyomás a globalizáció irányába. Nemzetek közötti rangsorokat felállító akkreditációs ügynökségek és öregdiákszövetségek alakulnak sorra, hogy a diákoknak és a kormányoknak segítsenek kiválasztani a nyerteseket. Ilyen rangsorok és ügynökségek segítségével teremtődik meg a különböző programok és iskolák elismertsége, és így válik láthatóvá azok piaci értéke.

\section{A társulások irányába mutató tényezők}

A fenntartható oktatási szolgáltatások körében - az IKT terjedése ellenére - a kísérleti, illetve „ad hoc” projektszakaszon való túljutásért továbbra is kemény küzdelem folyik. Erre a kihívásra az egyik leggyakoribb válasz a váltásokra lehetőséget kínáló társulások és más együttmúködési formák keresése. Divatos lett másokkal társulni, elsôsorban azért, mert az új piaci igények mellett önmagában egyetlen szervezet sem jelent elegendő vonzerőt és nem képes kielégítő szolgáltatásokat nyújtani. A digitális gazdaság termékeinek és szolgáltatásainak biztosításában különféle szervezeteknek együtt kell dolgozniuk. A piaci társulások és szövetségek robbanásszerú fejlődése mögött általános társadalmi-gazdasági erők is állnak, amelyek nem kizárólag az oktatást viszik előre.

A társulások kulcsfontosságú hajtóerôi többek között a következók:

- új piacok teremtése és kiaknázása, különösen az egész életen át tartó tanulás piaci lehetôsségeinek terén;

- új, illetve kibôvített szolgáltatások nyújtása;

- a meglévô szolgáltatások értékének növelése;

- az e-tanuláshoz szükséges anyagok fejlesztési költségeinek megosztása;

- a kockázatok megosztása több partner között;

- a tananyagok és más alkotóelemek több forrásból való biztosítása;

- az ismert márkanevek kiaknázása, illetve új márkanevek megteremtése;

- koncentráció az alaptevékenységekre, majd a feladatok „kicsomagolása”, illetve lebontása és kihelyezése;

- gazdaságossági előnyök.

$\mathrm{Az}$ egész életen át tartó tanulás és az e-tanulás ellátási láncában érintett résztvevôk a legkülönfélébb háttérrel és szervezeti kultúrával, készségekkel és jártasságokkal, kilátásokkal és célkitűzésekkel rendelkeznek. A magán szektor általában rövidtávra és a pénzügyi nyereségre koncentrál, míg az állami szektor - közszolgálati, közérdekű feladatait szem előtt tartva - hosszútávra tekint előre.

Az állami és magán célkitűzések közötti feszültségek kezelése

Az információs társadalom szempontjából kulcsfontosságúnak tartott ágazatokban krónikus finanszírozási hiány mutatkozik. Az iskolák, egyetemek, könyvtárak, múzeumok, kórházak és szociális szolgálatok még az „analóg” világban is küzdenek a tevékenységükhöz szükséges anyagi források megszerzéséért, és ez a küzdelem a digitális világban csak fokozódik. Az állami- és a magánszektor közötti társulások gyara- 
podása azt bizonyítja, hogy a kormányok átgondolják és átalakítják a közszolgálatok múködését. Az állami- és a magánszektor között könnyủ elmosni a határvonalat a szerepek és a felelősségek tekintetében, valamint abból a szempontból is, hogy kinek mit kell elvégezni, illetve megfizetni. Az állami- és a magánszektor közötti együttmúködéshez szilárd modellekre és irányelvekre van szükség. Az ilyen társulások lehetôséget teremtenek a mindenki hasznára váló új termékek és szolgáltatások fejlesztésének ösztönzésére.

\section{Kulcskérdések}

Az elmúlt években - mint már jeleztük - az IKT oktatási alkalmazásai terén történt jelentős mértékú ráfordítások és beruházások ellenére nem sok jel utal arra, hogy az IKT teljesíti a több ember jobb oktatásban való részesítésére vonatkozó ígéretét, az alacsonyabb költségekról nem is szólva. Mostanra komoly aggodalomra ad okot az IKT beruházások megtérülése.

Ennek okai többek között a következók:

- A nagyteljesítményű technológiák lehetőségeit kiaknázó kifinomult oktatási szoftverek fejlesztése elmaradt a technológia fejlődésének ütemétől. A kiváló minôségú oktatási szoftverek hiánya csalódásra ad okot, s elriasztja a tanárokat és a tanulókat az IKT tényleges használatától.

- Az OECD tanulmánya (OECD 1999) és a Kerrey-jelentés (Kerrey 2000) egyaránt felhívja a figyelmet a tanárok továbbképzésének elégtelenségére a technológia alkalmazása terén. A tanárok általában túl kevés, csupán elemi szintû́ és túlságosan általános jellegú képzésben részesülnek ahhoz, hogy a technológiát hatékony eszközként tudják használni a tanításban.

- A jelenlegi kereskedelmi forgalomban kapható oktatási szoftverek nagy része nehezen helyezhetô át az amerikai kontextusból máshová. Kevés olyan szoftver készült, amit más kulturális környezetben is fel lehet használni. A valóban globálisan felhasználható termékek igen ritkák az oktatási piacon.

- A hatékony on-line tananyagok és erőforrások választékában általános tartalmi hiányosságok mutatkoznak.

- Széles körben tapasztalható az analóg környezet utánzására való hajlam - ahelyett, hogy az új média kínálta lehetôségek kihasználásával digitális környezetet teremtenének vagy ötvöznék az analóg és a digitális média jellemzőit.

László Gábor

\section{Annotált források}

Collis, B. (1996): Tele-learning in a Digital World: The Future of Distance Learning. International Thomson Computer Press, London

OEGD (2001): E-learning: The Partnership Challenge, Education and Skills. 